\title{
6. Taking back control? Brexit and the Court of Justice
}

\section{Nikos Skoutaris·}

\section{Introduction}

On 23 June 2016, 52 per cent of voters that participated in the Brexit referendum voted to leave the EU. The message of the Leave Campaign to 'take back control' struck a chord with the majority of the electorate. Notwithstanding the separate reasons that led each and every one of those voters to vote in favour of the withdrawal of the UK from the EU, it is interesting to note that the UK government has interpreted this vote as an urge to shield the UK legal order from the influence of EU law. The prime minister, Theresa May, in her first speech in a party conference as leader of the Conservative party noted: 'Our laws [should be] made not in Brussels but in Westminster. Our judges [should be] sitting not in Luxembourg but in courts across the land. The authority of EU law in this country [should be] ended forever. ${ }^{11}$

The stance of the UK government towards EU law and its main interpreter, the Court of Justice is hardly surprising, if one takes into account the following. First, even from the very beginning of the UK's EU membership, the EU law principles of primacy and direct effect upon which the EU constitutional order is founded were sitting uncomfortably with parliamentary sovereignty which consists of the paramount principle of the UK legal order. Brexit offers an unprecedented opportunity to the UK legal order to 'divorce' from those 'foreign' legal principles that have created tectonic changes to it. Second, the result of the referendum shed light on the fact that the UK electorate was not in support of the current level of EU integration. Of course, 'integration is fundamentally a political process' but 'law has a vital role to play in the process. ${ }^{2}$ In that sense, the detachment of the UK legal order from that of the EU and its institutions is almost a logical consequence of that vote.

\footnotetext{
- Senior lecturer in EU law, UEA Law School.

${ }^{1}<$ https://www.telegraph.co.uk/news/2016/10/05/theresa-mays-conference-speech-in-full/> accessed 1 October 2018.

${ }^{2}$ Mauro Cappelletti, Monica Seccombe \& Joseph H.H. Weiler, '1.1 Integration through law' in Mauro Cappelletti, Monica Seccombe \& Joseph H.H. Weiler (eds.) Integration Through Law: Europe and the American Federal Experience (de Gruyter, 1985), 1.
} 
Having said that, the EU and the UK legal orders have been in a symbiotic relationship for more than four decades. To give but one example, there are thousands of directly applicable EU regulations, binding in their entirety, that have 'parachuted' within the UK legal order without any national transposing measure. So, an abrupt 'clean' end to that relationship would be almost impossible without the domestic legal order suffering from a seismic ripple effect. Moreover, given that the EU is a 'community of law', 'designing an ambitious economic partnership which respects the freedoms and principles of the EU, and the wishes of the British people' as the prime minister declared in her Florence speech $^{3}$ means that the Court of Justice of the European Union (CJEU) will inevitably be influencing the UK legal order for the foreseeable future.

The present chapter focuses on the aforementioned themes by analysing the relationship between the Court of Justice and the UK legal order after Brexit takes place. It revisits the challenge that the EU principles of primacy and direct effect raised for the UK constitutional order. It explains the role that the Agreement on the UK's Withdrawal from the EU (hereafter WA) envisages for the CJEU. ${ }^{4}$ Finally, it describes the role of the Court of Justice in the UK legal order after Brexit takes place by reference to the EU Withdrawal Act 2018 and the Agreement on the Future Relationship (hereafter FRA).

The analysis of the strained relationship between the UK and the EU and its apex court provided in this chapter can be seen in the broader context of the challenges that international organisations and international courts face at the moment from various states. The United States has not contributed to the United Nations Educational, Scientific and Cultural Organisation (UNESCO) budget since 2011 and plans to quit in 2018, while it has been delaying the process of appointments in the World Trade Organization (WTO) Appellate Body. Burundi left the International Criminal Court and it remains unclear whether South Africa will also exit the Rome Statute system. In that sense, the UK's withdrawal from the EU institutional framework is a symptom of a more widespread global phenomenon. At the same time, as a result both of the symbiotic relationship of the UK and EU legal orders and of the role that is envisaged for the

\footnotetext{
${ }^{3}<$ https:/www.gov.uk/government/speeches/pms-florence-speech-a-new-era-of-cooperation-and-partnershipbetween-the-uk-and-the-eu> accessed 1 October 2018.

${ }^{4}$ Draft Agreement on the withdrawal of the United Kingdom of Great Britain and Northern Ireland from the European Union and the European Atomic Energy Community, as agreed at negotiators' level on 14 November 2018. <https://ec.europa.eu/commission/sites/beta-political/files/draft_withdrawal_agreement_0.pdf $>$ accessed 1 December 2018.
} 
CJEU in the future relationship between the UK and the EU, the CJEU will remain an important actor in the UK order.

\section{The past: the UK and the judge-made EU law principles}

'The question of the legal status of norms of European Union law within the legal order of the Member States' has been omnipresent since the very first years of the life of the EU. ${ }^{5}$ Even at that early period, the Court of Justice understood the then European Economic Community as 'a new legal order of international law for the benefit of which the states have limited their sovereign rights, albeit within limited fields and the subjects of which comprise not only member states but also their nationals." ${ }^{6}$ As an answer to that question, the Court established the principles of direct effect and primacy (or supremacy) in its early case law. ${ }^{7}$

Direct effect allows individuals to rely on an EU law provision before a national court. It is the capacity of any EU law provision whose wording is clear, precise and unconditional to be applied in domestic court proceedings. ${ }^{8}$ At the same time, the Court in Costa held that whenever there is a conflict between a norm of EU law and one of national law, EU law ‘... could not ... be overridden by domestic legal provisions ... without being deprived of its character as [Union] law and without the legal basis of the [EU] itself being called into question." 9 This is why 'Primacy denotes the capacity of [an EU law provision] to overrule inconsistent norms of national law in domestic court proceedings. ${ }^{10}$ In Simmenthal, the CJEU went a step further by ruling that national courts have the power to disapply/set aside a national law provision and apply an EU law one in case they are in conflict. This may happen even in cases where the national legal framework does not provide the courts with such power of judicial review. ${ }^{11}$

\footnotetext{
${ }^{5}$ Bruno de Witte, 'Direct Effect, Primacy and the Nature of the Legal Order' in Paul Craig and Gráinne de Búrca (eds.), The Evolution of EU Law (2nd ed, OUP 2011) 323, 323.

${ }^{6}$ Case 26/62 NV Algemene Transport en Expeditie Onderneming Van Gend en Loos v Nederlandse administratie der belastingen, [1963] ECR 1.

${ }^{7}$ The two terms are used interchangeably in the English language literature. But the Court of Justice never refers to the term 'supremacy'.

${ }^{8}$ Van Gend en Loos (n 6).

${ }^{9}$ Case 6/64 Costa v ENEL [1964] ECR 585.

${ }^{10}$ De Witte (n 5).

${ }^{11}$ Case 106/77, Amministrazione delle Finanze v Simmenthal SpA [1978] ECR 629.
} 
Primacy and direct effect were 'certainly well established in the jurisprudence of the European Court of Justice long before the United Kingdom joined the [then] Community' ${ }^{12}$ It was foreseeable that those norms would sit somewhat uncomfortably with a legal order which is founded on the principle of parliamentary sovereignty.

According to the Diceyan orthodoxy, the principle of parliamentary sovereignty means 'that Parliament ... has, under the English Constitution, the right to make or unmake any law whatsoever; and, further, that no person or body recognised by the law of England as having a right to override or set aside the legislation of Parliament'. ${ }^{13}$ This means, first, that the UK Parliament possesses supreme lawmaking power that allows itself to pass legislation concerning anything. ${ }^{14}$ Second, no Parliament can bind its successors. Third, and more important for the purposes of the present chapter, a valid Act of Parliament cannot be set aside/disapplied by a court.

Bearing that in mind, the seismic impact of the Factortame decision is unsurprising. ${ }^{15}$ In that case, the then highest court of the land, the House of Lords disapplied - for the first time since the Glorious Revolution - an Act of the UK Parliament so as to give priority to a directly effective principle of EU law. The effect of EU law, however, has not been limited to introducing a limited form of judicial review in a constitutional system that is founded on parliamentary sovereignty. In Thoburn, Sir John Laws introduced the idea that the UK legal order recognises a hierarchy of statutes by accepting the distinction between 'ordinary statutes' and 'constitutional statutes'. ${ }^{16}$ The latter are immune from implied repeal. According to Lords Neuberger and Mance, '[T]he United Kingdom has no written constitution, but we have a

\footnotetext{
${ }^{12} R$ v Secretary of State for Transport ex p Factortame (No 2) [1991] 1 AC 603, para 379.

${ }^{13}$ Albert Venn Dicey, An Introduction to the Study of the Law of the Constitution (6th edn, Macmillan and Co, 1885) 40.

${ }^{14}$ For example, the Parliament can legislate on issues relating to itself (See Septennial Act 1716, Parliaments of 1910-1918, 1935-1945); with 'extra-territorial' effect (see War Crimes Act 1991); retrospectively (see Indemnity Act 1920 and War Charges Validity Act 1925; Enemy Property Act 1953); in (alleged) breach of International Law and the UK's international obligations

(Mortensen v Peters (1906) 8 F(J) 93, 100; Cheney v Conn [1968] 1 All ER 779,782); even immorally

(Madzimbamuto v Lardner-Burke [1969] 1 AC 645,723).

${ }^{15}$ Factortame (n 12).

${ }^{16}$ Thoburn v Sunderland City Council [2003] QB 151.
} 
number of constitutional instruments. They include [...] the European Communities Act 1972., ${ }^{17}$ This finding has been reaffirmed in Miller. ${ }^{18}$

So the influence of EU law in the transformation of the UK legal order cannot be overestimated. Lord Denning has described EU law as an ‘... incoming tide. It flows into the estuaries and up the rivers. ${ }^{19}$ It is therefore unsurprising that the UK government decided to limit, if not eliminate, the influence of EU law from the domestic legal order after Brexit takes place. In fact, Prime Minister Theresa May declared in her Lancaster House speech that after Brexit all laws governing the UK will be made in the UK and 'will be interpreted by judges not in Luxembourg but in courts across this country'. ${ }^{20}$ But can the UK legal order become watertight from the tide of EU law and CJEU case law even after Brexit takes place? A brief examination of the currently negotiated Withdrawal Agreement (WA) and the recently approved EU (Withdrawal) Act 1998 might suggest otherwise.

\section{The present I: the CJEU and the Withdrawal Agreement}

To start with, 'the Court of Justice of the European Union shall have jurisdiction as provided for in the Treaties' for the duration of the transition period. ${ }^{21}$ But even after the end of the transition, the CJEU and its case law will continue to play a significant role especially in the area of citizens's rights.

Despite the polarised rhetoric concerning free movement of persons during the Brexit referendum, the UK and the EU managed to agree fairly quickly on the issue of post-Brexit citizens' rights. Accordingly, all EU citizens residing at the UK and all UK citizens in the EU 27 at the end of the transition period (31 December 2020) will retain their rights of residence and work and most notably the right to equal treatment as currently derived from EU law. In the December Joint Report, the UK and the EU pointed out that the WA should 'enable the effective

\footnotetext{
${ }^{17}$ (HS2 Action Alliance Ltd) v Secretary of State for Transport [2014] UKSC 3, [207].

${ }^{18} R$ (on the application of Miller and another) $v$ Secretary of State for Exiting the European Union [2017] UKSC 5. [67].

${ }^{19}$ HP Bulmer Ltd v J Bollinger SA [1974] Ch 401, 418.

${ }^{20}$ Lancaster House Speech, The government's negotiating objectives for exiting the EU: PM speech, $<$ https://www.gov.uk/government/speeches/the-governments-negotiating-objectives-for-exiting-the-eu-pm-speech> accessed 1 October 2018.

${ }^{21}$ Art 131 WA.
} 
exercise of rights derived from Union law and based on past life choices. ${ }^{22}$ Part 2 of the WA (Articles 9 to 39) enshrines those rights through direct references to the relevant primary and secondary EU legislation including the citizens' rights Directive, ${ }^{23}$ Regulation $492 / 2011^{24}$ and Regulation $883 / 2004^{25}$

To protect those rights both for UK citizens living in the EU and EU citizens living in the UK and to give them legal certainty, the two parties accepted that appropriate mechanisms should be established $^{26}$ and that the CJEU is the "ultimate arbiter of the interpretation of EU law. ${ }^{27}$ So, the WA provides for a 'voluntary preliminary reference procedure'. According to Article 158 WA, the UK courts will be able to send preliminary references related to the part of the WA that regulates citizens' rights. This avenue of judicial assistance will be available for any litigation that has started up to eight years after the end of the transition period. The only difference between this voluntary procedure and the one described in Article 267 TFEU is that the UK courts of last instance will not be obliged to refer. In other words, the obligation of the courts of last instance to refer to the CJEU in accordance with Article 267(3) TFEU and the CILFIT case ${ }^{1 a w^{28}}$ on 'acte clair' will not be part of the legal framework established by the WA. Despite this, the Court of Justice will be able to influence the British legal life for a number of years after Brexit at least with regard to the very sensitive issue of citizens' rights.

However, citizens' rights is not the only area of the WA where a dispute settlement mechanism should be established. According to the European Council's guidelines, the WA 'should include appropriate dispute settlement and enforcement mechanisms regarding the application and interpretation of the [whole] withdrawal agreement'. ${ }^{29}$ According to Article $167 \mathrm{WA}$, the EU and

\footnotetext{
${ }^{22}$ Joint report from the negotiators of the European Union and the United Kingdom government on progress during phase 1 of negotiations under Article 50 TEU on the United Kingdom's orderly withdrawal from the European

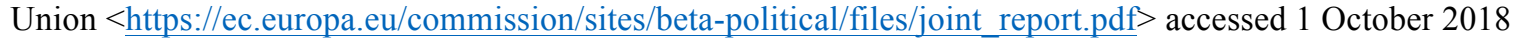

(hereafter Joint Report), para 6.

${ }^{23}$ Directive 2004/38/EC of the European Parliament and of the Council of 29 April 2004 on the right of citizens of the Union and their family members to move and reside freely within the territory of the Member States [2004] OJ L $158 / 77$.

${ }^{24}$ Regulation (EU) 492/2011 of the European Parliament and of the Council of 5 April 2011 on freedom of movement for workers within the Union [2011] OJ L141/1.

${ }^{25}$ Regulation (EC) No 883/2004 of the European Parliament and of the Council of 29 April 2004 on the coordination of social security systems [2004] OJ L 166/1.

${ }^{26}$ Joint Report, para 37.

${ }^{27}$ Ibid., para 38.

${ }^{28}$ Case 283/81 Srl CILFIT and Lanificio di Gavardo SpA v Ministry of Health ECLI:EU:C:1982:335.

${ }^{29}$ European Council Guidelines of 29 April 2017, point 17.
} 
the UK should 'make every attempt through cooperation and consultations' to reach a settlement of any dispute concerning the WA. Judicial mechanisms should be considered as a last resort when it comes to the settlement of any dispute. This is why at first instance, the two parties 'shall endeavour to resolve any dispute regarding the interpretation and application of the provisions of this Agreement by entering into consultations in the Joint Committee in good faith, with the aim of reaching a mutually agreed solution. ${ }^{30}$ Such Joint Committee will be comprised of representatives of both the UK and the EU. ${ }^{31}$

According to Article 170 WA, '[w] here no agreed solution can be reached, either party to the WA may request the establishment of an arbitration panel. ${ }^{32}$ The arbitration panel will be comprised of five persons. ${ }^{33}$ The EU and the UK will each nominate two persons from a list of ten they will have submitted by the end of the transition period. ${ }^{34}$ The chairperson will be selected by consensus by the four members of the panel. ${ }^{35}$ The existence of such arbitration panel was not part of the initial draft WA. As such, it "can be considered a negotiating success for the UK which had been pressing for an arbitration mechanism (instead of the ECJ as the ultimate arbiter). ${ }^{36}$

More interestingly, for the purposes of the chapter,

Where a dispute submitted to arbitration in accordance with this Title raises a question of interpretation of a concept of Union law, a question of interpretation of a provision of Union law referred to in this Agreement or a question of whether the United Kingdom has complied with its obligations under Article 89(2), the arbitration panel shall not decide on any such question. In such case, it shall request the Court of Justice of the European Union to give a ruling on the question. The Court of Justice of the European

\footnotetext{
${ }^{30}$ Art 169(1) WA.

${ }^{31}$ Art 164(1) WA.

32 Tobias Lock 'On Thin Ice: The Role of the Court of Justice under the Withdrawal Agreement', Verfassungsblog $<$ https://verfassungsblog.de/on-thin-ice-the-role-of-the-court-of-justice-under-the-withdrawal-agreement/> accessed 1 December 2018.

${ }^{33}$ Art 171(3) WA.

${ }^{34}$ Art 171(1) and (5) WA.

35 Ibid.

${ }^{36}$ Lock (n 32).
} 
Union shall have jurisdiction to give such a ruling which shall be binding on the arbitration panel. ${ }^{37}$

This means that notwithstanding the existence of an arbitration panel, the CJEU will still have an important role in the monitoring of the correct implementation of the WA.

Be that as it may, the biggest obstacle that the two parties faced in reaching an agreement on the WA related to the border between Ireland and the UK. Theresa May's government had been trying to find the balance between two seemingly irreconcilable goals. The UK aimed to leave the single market and the customs union, without returning to a hard border on the island of Ireland. $^{38}$

The text of the Joint Report, reached between the UK and the EU in December 2017 included a formula to 'square the circle'. It stated that the aim of the future trade negotiations would be to address the challenge of the Irish border through the overall EU-UK relationship. If the future trade agreement finds it impossible to provide for a frictionless invisible border, then, 'specific [technological] solutions' will apply to Northern Ireland. If the UK and the EU cannot agree on those 'specific solutions', then either the UK as a whole, or Northern Ireland, will remain aligned to the single market and the customs union after Brexit takes place. ${ }^{39}$

That third 'backstop option' was legally codified in a protocol contained in the Draft WA. It said that - should no specific solution be found - a common regulatory area comprising the European Union and Northern Ireland will be established and Northern Ireland will remain in the EU customs territory. May vehemently rejected the plan and said that 'No UK prime minister could agree to it ${ }^{40}$ because it 'threatens [the UK] constitutional integrity'. ${ }^{41}$ This is why the final draft of the WA included a significant compromise. According to it, the UK as a whole will be in a 'bare bones' customs union with the EU while Northern Ireland will remain aligned to those

\footnotetext{
${ }^{37}$ Art 174(1) WA.

${ }^{38}<$ http://www.independent.co.uk/news/uk/politics/article-50-letter-read-full-brexit-theresa-may-takes-uk-out-of-eustatement-a7655566.html> accessed 1 October 2018.

${ }^{39}$ Joint Report, para 49.

${ }^{40}<$ https:/www.irishtimes.com/news/world/theresa-may-rejects-draft-brexit-withdrawal-agreement-1.3409215> accessed 1 October 2018.

${ }^{41}$ Nikos Skoutaris, 'Why the EU's Brexit "backstop option” for Northern Ireland doesn't threaten the UK's constitutional integrity' < https://theconversation.com/why-the-eus-brexit-backstop-option-for-northern-irelanddoesnt-threaten-the-uks-constitutional-integrity-92869> accessed 1 October 2018.
} 
rules of the single market that are necessary to maintain the free movement of goods across the Irish border. $^{42}$

More interestingly for the purposes of the present chapter, the 'Court of Justice of the European Union shall have jurisdiction as provided for in the Treaties' with regard to the application of the EU acquis in Northern Ireland. ${ }^{43}$ In particular, the Court of Justice will have jurisdiction over the interpretation of EU customs legislation; ${ }^{44}$ the rules of the single market in goods as far as they apply under the backstop; ${ }^{45}$ VAT and excise rules; ${ }^{46}$ agriculture and environment; ${ }^{47}$ the single electricity market; ${ }^{48}$ and state aid. ${ }^{49}$ Thus, it is obvious that the CJEU will continue playing a significant role with regard to a part of the UK at least.

\section{The present II: the European Union (Withdrawal) Act 2018}

On 26 June 2018, the European Union (Withdrawal) Act 2018 received royal assent. The constitutional significance of that piece of legislation cannot be overstated. Section 1 repeals the European Communities Act 1972 which is considered one of the 'constitutional statutes' of the United Kingdom. ${ }^{50}$ Crucially, however, its purpose is to preserve and carry over into UK law the full body of EU law even after Brexit takes place as provided in sections 2, 3 and 4 of the Act.

The reason why a legislative act that was initially called 'the Great Repeal Act' 'copies and pastes' huge swathes of EU law in the legal order of a future third country is the following. Given the symbiotic relationship of the two legal orders for more than 40 years, there are thousands of directly applicable and directly effective pieces of EU law that would cease to apply to the UK after Brexit takes place. This would mean that legal vacuums would be created in a number of areas such as environmental law, consumer protection, workers' rights etc. In order to avoid such a situation, it was of utmost importance that the UK administration and Westminster would find a way to bridge those gaps without clogging up the parliamentary timetable for years to come.

\footnotetext{
${ }^{42}$ Protocol on Ireland/Northern Ireland, WA.

${ }^{43}$ Art 14(4), Protocol on Ireland/Northern Ireland, WA.

${ }^{44}$ Art 8, Protocol on Ireland/Northern Ireland, WA.

45 Ibid.

${ }^{46}$ Art 9, Protocol on Ireland/Northern Ireland, WA.

${ }^{47}$ Art 10, Protocol on Ireland/Northern Ireland, WA.

${ }^{48}$ Art 11, Protocol on Ireland/Northern Ireland, WA.

${ }^{49}$ Art 12, Protocol on Ireland/Northern Ireland, WA.

${ }^{50}$ Thoburn (n 16).
} 
Interestingly, the arrangement is very similar to the 'continuance clauses' of former colonies on independence from the UK as Douglas-Scott has noted. ${ }^{51}$ For instance, section $4(1)$ of the Constitution of Jamaica reads:

All laws which are in force in Jamaica immediately before the appointed day shall (subject to amendment or repeal by the authority having power to amend or repeal any such law) continue in force on and after that day, and all laws which have been made before that day but have not previously been brought into operation may (subject as aforesaid) be brought into force, in accordance with any provision in that behalf, on or after that day, but all such laws shall, subject to the provisions of this section, be construed, in relation to any period beginning on or after the appointed day, with such adaptations and modifications as may be necessary to bring them into conformity with the provisions of this Order. ${ }^{52}$

Be that as it may, section 5 of the EU (Withdrawal) Act addresses the role of the judge-made EU law principle of primacy post-Brexit. The general rule is that the principle of primacy does not apply to any UK law that is passed after the exit day. ${ }^{53}$ However, if Parliament intends that primacy should apply with regard to a certain post-Brexit legislative modification, then the UK courts should act accordingly. ${ }^{54}$ More importantly for the purposes of the present chapter, section 5(2) 'introduces a new legal hierarchy into the UK's constitutional system' ${ }^{55}$ According to this section, the principle of primacy will apply to retained EU law, that is to say, EU law that has been passed before Brexit including rights created by the case law of the $\mathrm{Court}^{56}$ as it relates to other pre-Brexit legislation. So, the retained EU law will have priority over any law enacted before Brexit pointing to the fact that the most important principle that was laid out by the Court will have a lasting effect in the UK legal order for years to come.

\footnotetext{
${ }^{51}$ Sionnaidh Douglas-Scott 'The 'Great Repeal Bill': Constitutional Chaos and Constitutional Crisis?', UK Constitutional Law Blog < https://ukconstitutionallaw.org/2016/10/10/sionaidh-douglas-scott-the-great-repeal-billconstitutional-chaos-and-constitutional-crisis/> accessed 1 October 2018.

52 Jamaican Constitution, s 4(1).

${ }^{53}$ EU (Withdrawal) Act, s 5(1).

${ }^{54}$ EU (Withdrawal) Act, s 5(3).

55 Jack Simson Caird, Vaughne Miller and Arabella Lang, 'European Union (Withdrawal) Bill' House of Commons Briefing Paper No 8079.

${ }^{56}$ EU (Withdrawal) Act, s 4(1).
} 
Consistent with the aim of the government to remove the influence of the CJEU on the UK legal order, ${ }^{57}$ section 6(1)(a) provides that after Brexit, the UK courts are 'not bound by any principles or decisions made ... by the European Court'. They are also prohibited from sending a preliminary reference question to the Court of Justice ${ }^{58}$ with the exception of cases on citizens' rights that are raised within the first eight years after the end of the transition period. However, even after Brexit takes place, any UK court may take into account the case law of the Court of Justice. ${ }^{59}$ In any case, UK courts regularly engage with the jurisdiction of foreign courts which they treat as persuasive but not a binding authority. In fact, the UK government has admitted that it is possible that 'Account is to be taken of CJEU decisions [...] where there is a shared interest in reducing or eliminating divergence in how specific aspects of an agreement with the EU are implemented. ${ }^{60}$

Concerning retained EU law, section 6(3) of the Act requires the UK courts to interpret the retained EU law 'in accordance with any retained case law and any retained general principles of EU law'. The term 'retained EU case law' refers to 'any principles laid down by, and any decisions of, the European Court, as they have effect in EU law' before Brexit unless there is an explicit exception either in section 5 or in Schedule $1 .{ }^{61}$ As previously discussed, section 5 excludes the principle of primacy of EU law. Schedule 1 on the other hand, provides that 'There is no right in domestic law [after Brexit takes place] to damages' for non-contractual state liability in accordance with Francovich. ${ }^{62}$

Notwithstanding those exceptions, it seems certain that the case law of the Court of Justice will influence the legal status of a significant part of UK legislation (namely, retained EU law) and as such the UK legal order. This body of legislation, in fact, will have primacy over any other piece of pre-Brexit national legislation.

\footnotetext{
${ }_{57}^{57}$ See Theresa May's speech in the 2016 Conservative Party conference (n 1).

${ }^{58}$ EU (Withdrawal) Act, s 6(1)(b).

${ }^{59}$ EU (Withdrawal) Act, s 6(2).

${ }^{60}$ Department for Exiting the EU, 'Enforcement and Dispute Resolution - A Future Partnership Paper' $<$ https://www.gov.uk/government/publications/enforcement-and-dispute-resolution-a-future-partnership-paper $>$ accessed 1 October 2018.

${ }^{61} \mathrm{EU}$ (Withdrawal) Act, s 6(7).

62 Joined Cases C-6/90 and C-9/90, Francovich and Bonifaci v Italy ECLI:EU:C:1991:428.
} 
However, not all the UK courts will be obliged to provide for legal continuity by following the retained EU law. The UK Supreme Court and the Scottish High Court of Judiciary are asked to treat this retained EU case law in the same way that they would treat their own. ${ }^{63}$

So far, we have seen how the WA - which at the time of writing is still being negotiated - and the recently approved EU (Withdrawal) Act will allow the Court of Justice and its wellestablished case law to influence the UK legal order even after Brexit takes place. A question remains, however, as to what the influence of the Court will be in the future relationship between the UK and the EU. How might the Agreement on the Future Relationship (hereafter FRA) - that will only be negotiated once the UK becomes a non-member of the EU- envisage the role of the CJEU?

\section{The future: the future agreement}

According to Article 50(2) TEU (Treaty on European Union), the EU 'shall negotiate and conclude an agreement with [the UK], setting out the arrangements for its withdrawal taking account of the framework for its future relationship with the Union.' Indeed, a political declaration that sets out the framework of the future UK-EU relationships was published at the same time as the WA. ${ }^{64}$ The negotiations for the agreement, however, will only start after Brexit takes place on 29 March 2019 and will be conducted in accordance with Article 218 TFEU (Treaty on the Functioning of the European Union). The latter is of significant importance. It means that the FRA may be subject to an opinion of the CJEU according to Article 218(11) TFEU.

The Court has a long history of judicially reviewing international agreements of the EU with often unexpected results. A recent example is Opinion 1/13 where the Court struck down the agreement on the accession of the EU to the European Convention on Human Rights (ECHR) because it violated the principle of autonomy of the Union legal order, among other things. ${ }^{65}$ It

\footnotetext{
${ }^{63}$ EU (Withdrawal) Act, s 6(5).

${ }^{64}$ Political Declaration Setting out the Framework for the Future Relationship between the European Union and the United Kingdom (hereafter Political Declaration) $<$ https://assets.publishing.service.gov.uk/government/uploads/system/uploads/attachment data/file/758557/22 Nove mber Draft Political Declaration setting out the framework for the future relationship between the EU and the UK agreed at negotiators level and agreed in principle at political level subject to endorsement by Leaders.pdf $>$ accessed 1 December 2018.

${ }^{65}$ Opinion 2/13 Re Accession of the EU to the ECHR ECLI:EU:C:2014:2454.
} 
did so, despite the fact that it took part both in the negotiations and in the drafting of that agreement. So, given its history in judicially reviewing international agreements, it is important to understand the limits that its case law sets in designing the dispute settlement mechanisms of the FRA.

The EU has made clear from the beginning that any dispute settlement scheme would need to respect the principle of autonomy of the Union legal order including the role of the Court of Justice $^{66}$ and the UK has tacitly accepted that. ${ }^{67}$ According to the settled case law of the CJEU, this principle sets certain constraints in the event that international agreements concluded by the EU provide for dispute settlement through judicial or quasi-judicial bodies other than the Court of Justice itself. Such dispute settlement bodies 'must not have the effect of binding the EU and its institutions, in the exercise of their internal powers, to a particular interpretation of the rules of EU law'. ${ }^{68}$ So any judicial or quasi-judicial body established by the Agreement on the postBrexit relationship of the EU with the UK to settle disputes may not interpret provisions 'which are identical to provisions of [Union] law'. ${ }^{69}$ Finally, it is possible for the agreement on the future relationship to 'confer new powers on the Court, provided that in so doing it does not change the nature of [its] function' as conceived in the EU treaties. ${ }^{70}$

Recently, the UK put forward a blueprint for the future relationship: the Chequers agreement. ${ }^{71}$ The new plan proposes to establish a free trade area for goods between the UK and the EU where 'a common rulebook for goods including agri-food' will exist. ${ }^{72}$ The UK will commit, by international agreement, 'to ongoing harmonisation with EU rules on goods'. ${ }^{73}$ This echoes the mechanism of the European Economic Area whose members have to adopt the new or reformed regulations that the EU institutions produce. At the same time, the government

\footnotetext{
${ }^{66}$ See points 1 and 17 of the European Council Guidelines of 29 April 2017; point 39 of the Negotiating Directives.

${ }^{67}$ Political Declaration, para 83.

${ }^{68}$ Opinion 2/13 (n 65) para 184 citing Opinions 1/91, EU:C:1991:490, paras 30 to 35; and 1/00, EU:C:2002:231, para 13.

${ }^{69}$ Opinion 1/92 Re EEA, ECLI:EU:C:1992:189, para 36.

${ }^{70}$ Ibid., para 32.

${ }^{71}$ White Paper on 'The Future Relationship between the United Kingdom and the European Union'

$<$ https://www.gov.uk/government/publications/the-future-relationship-between-the-united-kingdom-and-theeuropean-union $>$ accessed 1 October 2018.

${ }^{72}$ Ibid.

${ }^{73}$ Ibid.
} 
contends that parliament can guard the UK legal order from future EU legislation in an arrangement that somehow resembles the EU's relationship with Switzerland.

Be that as it may, in the White Paper on the future relationship, the UK states that disputes under this arrangement should be raised in the Joint Committee comprised of representatives both of the UK and the EU. In the event that the Committee fails to resolve the dispute by negotiation, an independent arbitration panel should be formed. ${ }^{74}$ In the area of goods where the UK has decided to adhere to the common rulebook, a referral to the CJEU for interpretation of the relevant rules will also be available to the Joint Committee and the arbitration panel. ${ }^{75}$ In other words, the UK wants to opt for a system of dispute resolution through arbitration with an in-built possibility of referring to the Court of Justice, similar to the WA. The EU has accepted that in principle. ${ }^{76}$ This again shows that the influence of the CJEU to the UK legal order will remain significant for years to come.

To be sure, the negotiations on the future relationship have barely started while the EU has remained lukewarm if not totally unconvinced with regard to the Chequers proposal. ${ }^{77}$ Having said that, it is worth noting two distinct but interrelated issues that relate to the dispute resolution system that the Political Declaration favours. There is nothing particularly innovative about the establishment of a Joint Committee as the primary venue of dispute settlement. Apart from the WA itself that provides for such a body, a number of free trade agreements also establish a Joint Committee responsible for the overall functioning of the agreement. Such Committee has the primary role for resolving disputes through negotiations. The recent EU-Singapore Free Trade Agreement, for instance, establishes a Trade Committee. ${ }^{78}$

The Trade Committee shall:

(a) ensure that this Agreement operates properly;

(b) supervise and facilitate the implementation and application of this Agreement, and further its general aims;

\footnotetext{
74 Ibid. 93.

${ }^{75}$ Ibid.

${ }^{76}$ Political Declaration, para 134.

$77<$ https://www.independent.co.uk/news/uk/politics/brexit-michel-barnier-theresa-may-chequers-proposal-no-dealeu-a8519636.html > accessed 1 October 2018.

${ }^{78}$ Free Trade Agreement between the European Union and the Republic of Singapore, Article 16.1.
} 
(c) supervise the work of all specialised committees, working groups and other bodies established under this Agreement;

(d) consider ways to further enhance trade relations between the Parties;

(e) without prejudice to Chapter Fourteen (Dispute Settlement) and Chapter Fifteen (Mediation Mechanism), seek to solve problems which might arise in areas covered by this Agreement, or resolve disputes that may arise regarding the interpretation or application of this Agreement; and

(f) consider any other matter of interest relating to an area covered by this Agreement. ${ }^{79}$

Second, given the insistence of the Court of Justice on the principle of autonomy, an arbitration system could only be established if there was a mandatory preliminary reference procedure from the arbitration to the CJEU whenever the dispute turned on interpretation of a reference to EU law or a concept identical to EU law. Such mandatory preliminary reference procedures exist already in a few international agreements concluded between the EU and non-members of the EU. For example, Articles 267 of the EU-Georgia Association Agreement, ${ }^{80} 322$ of the EUUkraine Association Agreement, ${ }^{81}$ and 403 of the EU-Moldova Association Agreement ${ }^{82}$ provide that 'Where a dispute raises a question of interpretation of a provision of Union law [...], the arbitration panel shall not decide the question, but request the Court of Justice of the European Union to give a ruling on the question [...] The ruling of the Court of Justice of the European Union shall be binding on the arbitration panel.'

The difference with the aforementioned models, however, will be the scope of such arbitration system. Given the ambition of the future relationship, it is expected that the EU-UK arbitration system will have largely unprecedented competence in international law practice as it could reach far beyond trade disputes and extend across many areas of law. And if within this dispute settlement mechanism there is space for a mandatory preliminary reference procedure, the influence of the Court of Justice will continue in the post-Brexit era.

\footnotetext{
${ }^{79}$ Ibid.

${ }^{80}$ Council Decision of 16 June 2014 on the signing, on behalf of the European Union, and provisional application of the Association Agreement between the European Union and the European Atomic Energy Community and their Member States, of the one part, and Georgia, of the other part (2014) OJ L261/1.

${ }^{81}$ Association Agreement between the European Union and its Member States, of the one part, and Ukraine, (2014) OJ L161/3.

${ }^{82}$ Association Agreement between the European Union and the European Atomic Energy Community and their Member States, of the one part, and the Republic of Moldova, of the other part (2014) OJ L260/4.
} 


\section{Conclusion}

Brexit is arguably the most significant constitutional moment for the UK in decades. The gradual detachment of the UK legal order from the EU, with which the UK has shared more than 40 years of symbiotic relationship, raises a number of questions, one of which relates to the role of the main arbiter and interpreter of EU law, the Court of Justice.

The UK government has declared that in 'taking back control of its laws' it needs to distance itself from the jurisprudence of the Court of Justice and should put an end to the primacy of its case law. It is true that the role of the Court of Justice and EU law in general will be more limited after Brexit takes place than it is at present. However, it is almost impossible to envisage the UK legal order becoming completely 'watertight' from the 'tide' of EU law.

The WA that regulates the terms of withdrawal of the UK provides for a significant role for the CJEU with regard to citizens' rights and with regard to dispute settlement more generally. If there is a compromise on the 'Irish border question' along the lines described by the Commission, the CJEU will also remain a court for part of the UK. In addition, the terms of the EU (Withdrawal) Act acknowledge that UK courts will be influenced by the case law of the Luxembourg court. Finally, the principle of autonomy suggests that an ambitious FRA should acknowledge and take into account the role of the CJEU.

In other words, the rumours of the death of the CJEU are greatly exaggerated ... 
